\title{
PENGALAMAN KELUARGA DALAM MERAWAT PASIEN PASCAPASUNG
}

\author{
Wahyu Reknoningsih ${ }^{1 *}$, Novy Helena Catharina Daulima ${ }^{2}$, Yossie Susanti Eka Putri ${ }^{2}$
}

1. Program Studi Magister, Fakultas Ilmu Keperawatan, Universitas Indonesia, Depok 16424, Indonesia

2. Fakultas Ilmu Keperawatan, Universitas Indonesia, Depok 16424, Indonesia

*E-mail: wahyu_rekno@yahoo.com

\begin{abstract}
Abstrak
Pasien pasung yang telah pulang dari rumah sakit jiwa (RSJ) oleh keluarga akan berpotensi untuk dipasung kembali. Tujuan penelitian menguraikan pengalaman keluarga dalam merawat pasien pascapasung. Desain penelitian kualitatif dengan pendekatan fenomenologi. Teknik pengambilan purposive sampling dengan wawancara mendalam. Kriteria inklusi caregiver yang mempunyai anggota keluarga pernah dipasung sebelum dan sesudah dirawat di RSJ dan mampu berkomunikasi. Hasil penelitian menunjukkan bahwa keluarga pasien pascapasung mengalami beban emosional dan kelelahan fisik. Rekomendasi penelitian adalah berupa pengembangan pelayanan keperawatan jiwa di masyarakat dan pemberian pendidikan kesehatan dengan cara penanganan pasien gangguan jiwa dengan perilaku agresif.
\end{abstract}

Kata kunci: caregiver, pasung, perilaku agresif

\section{Abstract}

Phenomenology Study on the Family's Experience in Caring for Client Post Restraint (Seclusion) in Central Java. The seclusion or restraint's client will send home to their family was experienced re restraint or re seclusion. The aim of this study is to elaborate the family's experience in caring for the client post restraint or seclusion through the qualitative study with the phenomenology approach. The sampling technique is purposive sampling with in-depth interview. The inclusion criteria are the caregiver who has a family member with the experience of being restraint or seclusion before hospitalized, had been restraint, being restraint or being re-restraint, and being able to communicate well. The results show that the family have emotional burden and physical exhausted. This study has suggested that psychiatric nursing may develop a mental nurse psychiatric nursing services in the community by providing health education on how to manage the aggressive behavior of the client with mental disorder.

Keywords: the experience, caregiver, restraint (seclusion)

\section{Pendahuluan}

Kementerian Kesehatan (2010) menjelaskan seseorang dengan gangguan jiwa atau disebut dengan orang dengan masalah kejiwaan (ODMK) umumnya mengalami stigma, diskriminasi dan marginalisasi. Diskriminasi dan marginalisasi pada ODMK berupa individu dipandang "sebelah mata" atau mengalami ketidakadilan dalam memperoleh akses kehidupan, seperti pendidikan dan kesehatan. Stigma adalah pandangan negatif masyarakat yang melihat ODMK sebagai aib karena kutukan atau kemasukan roh, mengganggu, membahayakan orang lain, dan membebani masyarakat. Dampak ODMK, biasanya, keluarga seringkali dikucilkan oleh masyarakat. Bahkan sebagian dari mereka ada yang dipasung dengan kondisi yang sangat memprihatinkan, seperti dipasung dengan kayu, dirantai, dikandangkan, atau diasingkan di tengah hutan yang jauh dari masyarakat.

Maramis (2006) menjelaskan pasung sebagai tindakan memasang sebuah balok kayu pada tangan dan atau kaki seseorang, diikat atau dirantai lalu diasingkan pada suatu tempat tersendiri di dalam rumah ataupun di hutan. Istilah lain pasung adalah pengikatan (restrain). Menurut Councel and Care UK (2002) (dalam Royal Collage of Nursing, 2008), restrain merupakan tindakan membatasi atau mengekang seseorang dengan 
sengaja untuk bergerak sesuka hatinya atau berperilaku. Menurut Dinas Kesehatan Bireuen (2008), jumlah pasien pasung di wilayah Bireuen dalam periode 2005 sampai dengan 2008 berjumlah 49 orang. Di sisi lain, Nevi (2012) mengungkapkan data dari Dinas Kesehatan Provinsi Jawa Tengah mencatat 200 orang gangguan jiwa telah mengalami pasung.

Berdasarkan data rekam medik rumah sakit jiwa (RSJ) Amino Gondohutomo, Semarang pada Desember 2012, diketahui jumlah pasien pasung yang telah dirawat sejak tahun 2011 sampai dengan Desember 2012 sebanyak 343 orang yang pulang ke rumah. Pasien pascapasung yang telah dirawat di RSJ dan dikembalikan pada keluarga adalah pasien dalam masa pengobatan dan penyembuhan karena mereka masih terus minum obat dan melakukan kontrol kesehatan, baik di rumah sakit maupun Pusat Kesehatan Masyarakat (Puskesmas), yang masih menunjukkan perilaku agresif seperti mudah marah dan mengamuk sehingga berdampak pada keluarga melakukan pemasungan kembali.

\section{Metode}

Desain penelitian menggunakan penelitian kualitatif dengan pendekatan fenomenologi. Partisipan penelitian ini adalah keluarga atau caregiver pasien pascapasung yang pernah atau sedang mengalami pemasungan ulang. Jumlah partisipan berjumlah tujuh orang hingga saturasi data. Tempat penelitian ini dilaksanakan di Kabupaten Pekalongan pada Mei 2013. Wawancara mendalam dilakukan selama 30-35 menit. Analisis data penelitian menggunakan langkah-langkah, yaitu membuat transkripsi verbatim, membaca trankripsi secara berulang-ulang, mengumpulkan pernyataan yang signifikan, menentukan kata kunci dari setiap pernyataan yang penting, mengelompokkan ke dalam kategori, menyusun, dan mengelompokkan menjadi tema yang sesuai dengan tujuan penelitian.

\section{Hasil}

Partisipan terdiri atas satu orang laki-laki dan enam orang perempuan dengan usia dewasa
(30-59 tahun). Partisipan memiliki anggota keluarga yang menjalani dua kali perawatan di RSJ. Karakteristik partisipan secara lengkap dapat dilihat pada Tabel 1.

Pengalaman keluarga merawat pasien pascapasung, didapatkan lima tema sebagai berikut.

Kelelahan fisik dan pergolakan emosi sebagai dampak merawat. Dampak merawat pasien pascapasung disikapi oleh partisipan dengan munculnya kelelahan fisik dan pergolakan emosi yang dirasakan keluarga. Dampak merawat pasien pascapasung berupa kelelahan fisik, yaitu menghabiskan tenaga atau energi, pusing, dan tekanan darah rendah, seperti yang diungkapkan partisipan berikut.

"Ya capai terus, Bu..." (P2).

"Capai melayani terus..,sampai pikirannya pusing, kadang tensi saya rendah ...” (P1).

Dampak merawat pasien pascapasung pada keluarga juga terjadi pergolakan emosi keluarga. Sebagian besar partisipan mengeluhkan adanya rasa marah dan jengkel, seperti dalam wawancaranya berikut.

"Ya marah, jengkel, terus terang saja ya bu...”(P1).

Tidak jarang terjadi emosi marah dan jengkel diungkapkan secara langsung pada pasien dengan menyuruh pasien pergi dari rumah daripada membuat marah keluarga, seperti dalam penuturannya:

"Ya bosan, jengkel sampai muncul ucapan pergi saja.”(P1).

Emosi marah juga disampaikan oleh partisipan lain dengan memikirkannya di dalam hati seperti dalam ungkapannya berikut.

"Sampai saya berpikir, ya, Tuhan kalau mau meninggal, ya, jangan kelamaan...” (P4).

Beberapa partisipan mengungkapkan rasa malu dengan adanya pasien pascapasung sebagai bagian dari keluarga. Mereka malu mempunyai anggota keluarga dengan gangguan mental, seperti dalam ungkapannya berikut. 
Tabel 1. Karakteristik Partisipan

\begin{tabular}{|c|c|c|c|c|c|c|c|}
\hline \multirow{2}{*}{ Jenis Penggolongan } & \multicolumn{7}{|c|}{ Partisipan } \\
\hline & P1 & P2 & P3 & P4 & P5 & P6 & P7 \\
\hline a. Jenis Kelamin & Perempuan & Perempuan & Perempuan & Perempuan & Laki-laki & Perempuan & Perempuan \\
\hline b.Usia (tahun) & 36 & 58 & 50 & 58 & 56 & 30 & 58 \\
\hline c.Hubungan dg Pasien & Adik & $\begin{array}{l}\text { Ibu } \\
\text { Kandung }\end{array}$ & $\begin{array}{l}\text { Ibu } \\
\text { Kandung }\end{array}$ & $\begin{array}{l}\text { Ibu } \\
\text { Kandung }\end{array}$ & $\begin{array}{l}\text { Bapak } \\
\text { Kandung }\end{array}$ & $\begin{array}{l}\text { Adik } \\
\text { kandung }\end{array}$ & $\begin{array}{l}\text { Ibu } \\
\text { Kandung }\end{array}$ \\
\hline d.Agama & Islam & Islam & Islam & Islam & Islam & Islam & Islam \\
\hline e.Status Perkawinan & Menikah & Janda & Menikah & Menikah & Menikah & Menikah & Menikah \\
\hline f.Pendidikan & SD & $\begin{array}{l}\text { Tidak } \\
\text { Sekolah }\end{array}$ & $\begin{array}{l}\text { Tidak } \\
\text { Sekolah }\end{array}$ & SD & $\begin{array}{l}\text { Tidak } \\
\text { Sekolah }\end{array}$ & SD & $\begin{array}{l}\text { Tidak } \\
\text { Sekolah }\end{array}$ \\
\hline g.Pekerjaan & IRT & IRT & IRT & Buruh & Buruh Jahit & IRT & Jualan Sayur \\
\hline $\begin{array}{l}\text { h.Berapa kali pasien } \\
\text { dirawat di RSJ }\end{array}$ & 2 kali & 2 kali & 2 kali & 2 kali & 3 kali & 2 kali & 1 kali \\
\hline $\begin{array}{l}\text { i.Bentuk pemasungan } \\
\text { ulang terhadap pasien }\end{array}$ & $\begin{array}{l}\text { Dirantai } \\
\text { dan } \\
\text { dikunci di } \\
\text { kamar }\end{array}$ & $\begin{array}{l}\text { Dikurung di } \\
\text { kamar }\end{array}$ & $\begin{array}{l}\text { Diikat } \\
\text { dengan tali } \\
\text { \& dikunci di } \\
\text { kamar }\end{array}$ & $\begin{array}{l}\text { Dirantai di } \\
\text { dalam } \\
\text { rumah }\end{array}$ & $\begin{array}{l}\text { Dikunci di } \\
\text { kamar }\end{array}$ & $\begin{array}{l}\text { Dirantai dgn } \\
\text { rantai } \\
\text { panjang di } \\
\text { dlm rumah }\end{array}$ & $\begin{array}{l}\text { Dikunci di } \\
\text { dalam } \\
\text { kamar }\end{array}$ \\
\hline
\end{tabular}

"Ya malu karena mengganggu orang lain..."(P5).

Kesulitan keluarga dalam manajemen beban. Pada tema kedua ini, peneliti menemukan bahwa keluarga pasien pascapasung mengalami kesulitan manajemen beban dalam merawat keluarga yang mengalami keterbatasan tenaga untuk menemani atau mengawasi pasien. Kesulitan inilah yang menjadikan keluarga memilih untuk kembali melakukan pemasungan terhadap pasien pascapasung.

Keterbatasan keluarga dalam membagi bebannya dinyatakan oleh partisipan dengan menjelaskan bahwa keluarga mengalami kesibukan karena keluarga juga harus mengurus suami dan anaknya di samping mengurus pasien, seperti dalam wawancaranya berikut ini.

“....Bagaimana lagi ya bu, saya sudah sibuk jadi ya dirantai lagi.”(P1).

Keterbatasan juga dijelaskan lebih lanjut oleh partisipan karena tidak adanya anggota keluarga lain yang membantu merawat pasien, seperti wawancara di bawah ini.
"Ya, tidak ada yang mengawasi, tenaganya tidak ada, pada kerja semua."(P2).

Bentuk kesulitan keluarga dalam manajemen beban juga terlihat dari adanya risiko berat yang harus ditanggung oleh pasien apabila pasien dibiarkan keluar rumah tanpa pengawasan. Kehamilan maupun pelecehan seksual dapat terjadi pada pasien wanita pascapasung, seperti disampaikan partisipan dalam wawancaranya berikut.

“..Soalnya bahaya kalau hilang, takut diapaapain orang (dihamili)"(P2).

\section{Perilaku agresif sebagai alasan pemasungan} ulang. Pada tema ketiga ini, peneliti menemukan alasan keluarga melakukan pemasungan ulang pada pasien adalah karena perilaku agresif pasien yang mengganggu keluarga dan lingkungan.

Perilaku agresif pasien yang mengganggu lingkungan dinyatakan oleh sebagian besar partisipan dengan menjelaskan bahwa pasien mengganggu tetangga di sekitarnya dengan berteriak-teriak, makan jajanan di warung tidak membayar, memukul, mengejar orang yang lewat di sekitar pasien, 
mengamuk, dan merusak kaca, seperti dalam wawancaranya berikut.

“...Kalau tidur tembok dicongkeli, kalau di warung banyak hutang, sama siapa saja memukul, mengejar-kejar."(P4).

Selain perilaku agresif pasien yang mengganggu lingkungan, ditemukan pula perilaku agresif pasien yang mengganggu keluarga dengan selalu marah dan mengamuk bila keinginannya tidak dipenuhi keluarga, seperti dalam wawancaranya berikut.

"Ya, di rumah marahan, suka mengamuk..." (P3).

Selain mengamuk dan merusak, pasien juga menunjukkan sikap kasar terhadap keluarga dengan berbicara kurang sopan dan melemparkan makanan ke arah muka, seperti dalam ungkapannya sebagai berikut.

“...kalau memberi makan saya lewat jendela tapi nanti dilemparkan ke saya.”(P4).

\section{Bentuk Dukungan Internal dan Eksternal} pada Keluarga dalam Merawat. Dukungan dalam me-rawat pasien pascapasung sangat penting bagi keluarga. Berbagai bentuk dukungan yang peneliti temukan pada penelitian ini berasal dari dukungan internal dan dukungan eksternal. Dukungan internal didapatkan dari dalam keluarga besar pasien sendiri, sedangkan dukungan eksternal diperoleh dari luar keluarga, yaitu dari pemerintah dan lingkungan.

Bentuk dukungan keluarga besar terhadap partisipan dalam merawat pasien pascapasung dilakukan dengan membantu memenuhi kebutuhan dasar pasien, seperti dalam wawancara berikut.

"Ya memberi makan, membersihkan kotoran, memakaikan baju, memandikan gitu, Bu.”(P6).

Selain memenuhi kebutuhan dasar pasien, bentuk dukungan internal juga diberikan dengan memenuhi kebutuhan sosial pasien, yaitu dengan mengajak pasien bicara untuk mengajak berdoa atau berzikir, seperti dalam ungkapannya berikut.
"Kalau isteri adik mengajak bicara bila lagi nyambung..."(P2).

Selain dukungan keluarga dalam bentuk pemenuhan kebutuhan dasar dan kebutuhan sosial pasien, bantuan materiil berupa uang dan beras juga diperoleh caregiver dari keluarga besar, seperti dalam wawancaranya berikut.

"Ya kadang memberi beras, uang tapi tidak rutin.”(P4).

Bentuk dukungan keluarga yang tidak kalah penting juga diperoleh partisipan berupa doa supaya pasien cepat sembuh dan keluarga diberi kekuatan, seperti dalam wawancaranya berikut ini.

\section{“..Nggih mereka juga mendoakan”(P7).}

Selain bentuk dukungan internal, peneliti juga menemukan bentuk dukungan eksternal pada keluarga berupa dukungan dana dari pemerintah dan dukungan lingkungan. Bentuk dukungan dana pemerintah yang dimaksud dalam penelitian ini adalah fasilitas pelayanan kesehatan gratis untuk mengecek kondisi pasien dan pengobatan lanjutan gratis di puskesmas yang dekat dengan tempat tinggal pasien, seperti dalam wawancaranya berikut.

“...Alhamdulillah dibantu, biaya dirawat dari pemerintah, obat ya dari puskesmas.”(P7).

Sebagian besar partisipan menyatakan bahwa tetangga sekitar sering menanyakan kondisi pasien, seperti dalam wawancarannya berikut.

“...Ya, mereka sering menanyakan kondisi Mawar.”(P1).

Selain itu, dukungan lingkungan lainnya dinyatakan oleh partisipan dengan mengingatkan pasien untuk memakai baju bila tetangga mendapati pasien sedang tidak memakai baju di luar rumah, seperti dalam wawancaranya berikut.

“...kadang mereka mengingatkan bila tidak pakai baju untuk pulang ke rumah...”(Pl). 
Bentuk dukungan lingkungan lain yang tidak kalah penting adalah kepedulian aparat desa yang berusaha mencarikan bantuan dana bagi keluarga, meskipun sampai saat ini keluarga belum menerima bantuan dari desa, seperti dinyatakan partisipan berikut ini.

“...tidak ada yang menghina, perangkat desa mengusahakan bantuan”(P7).

\section{Peningkatan Pemahaman Spiritualitas sebagai}

Hikmah Merawat. Pengalaman keluarga dalam merawat pasien pascapasung merupakan pembe-lajaran nyata yang telah dialami keluarga. Hikmah merawat pasien pascapasung bagi keluarga terlihat dari meningkatnya pemahaman spiritualitas ke-luarga. Pemahaman spiritualitas bersifat unik bagi setiap orang bergantung dari budaya, per-kembangan, pengalaman hidup, kepercayaan, dan ide-ide tentang kehidupannya. Spiritualitas dijelaskan dalam dimensi keterhubungan sebagai keterhubungan dengan diri sendiri (intrapersonal), keterhubungan dengan orang lain (interpersonal), dan keterhubungan dengan Tuhan (transpersonal).

Meningkatkan pemahaman spiritualitas keluarga berupa penerimaan diri ditunjukkan oleh dua partisipan dengan menjadi lebih sabar dan satu partisipan menjadi tidak mudah marah, seperti dalam wawancaranya berikut ini.

"Ya, tidak apa-apa, lebih sabar, tidak cepat marah”(P2).

Selain lebih sabar dan tidak mudah marah, satu partisipan merasakan banyak berkah yang diterima dalam merawat pasien pascapasung, seperti dalam wawancaranya berikut.

"Hikmahnya, ya berkah, masih bisa berdoa, ikut pengajian, mengurus keluarga”(P7).

Meningkatnya pemahaman spiritualitas keluarga juga digambarkan dalam bentuk kedekatan keluarga kepada Tuhan dengan menganggap merawat pasien pascapasung sebagai takdir yang diungkapkan oleh tiga partisipan, bersikap pasrah diungkapkan oleh satu partisipan, dan menganggap sebagai cobaan/ujian dari Tuhan diungkapkan oleh dua partisipan serta lebih mendekatkan diri kepada Tuhan diungkapkan oleh dua partisipan, seperti dalam wawancaranya berikut.

“...ya gimana lagi sudah takdir, namanya sakit ya harus diusahakan”(P5).

Hubungan positif keluarga dengan lingkungan diungkapkan oleh satu partisipan dengan bisa ikut pengajian serta perkumpulan ibu-ibu di wilayahnya, seperti dalam ungkapannya :berikut.

"Nggih, jadi sering ikut pengajian sama kumpulan ibi-ibu, saya tidak apa-apa" (P7).

\section{Pembahasan}

Hasil penelitian menunjukkan bahwa seluruh keluarga yang menjadi caregiver/partisipan pasien pascapasung berada pada rentang usia dewasa penuh yaitu 30-59 tahun, sedangkan enam dari tujuh orang partisipan berjenis kelamin perempuan, yaitu empat orang merupakan ibu kandung pasien dan dua orang adalah adik kandung pasien.

Lebih dominannya perempuan dibanding lakilaki sebagai caregiver dalam penelitian ini, sejalan dengan hasil penelitian yang dilakukan oleh Jankovic, et al. (2011); Hou, Ke, Sue, Lung dan Huang (2008); Hanzawa, Tanaka, Inadomi dan Urata (2008) yang menyatakan bahwa sebagian besar caregiver pasien schizophrenia di London, Taiwan, dan Jepang adalah orang tua perempuan atau ibu pasien sendiri.

Penelitian ini juga menemukan bahwa usia caregiver bagi pasien pascapasung berada pada rentang usia dewasa (30-59 tahun). Penelitian yang dilakukan Hou, Ke, Sue, Lung dan Huang (2008) menjelaskan bahwa rata-rata usia keluarga yang menjadi caregiver bagi pasien schizophrenia di Taiwan adalah 55 tahun, sedangkan Yusuf dan Nuhu (2011) menjelaskan bahwa rata-rata usia caregiver pasien schizophrenia adalah 45 tahun dan rata-rata mempunyai stres emosional yang tinggi. 
Tema 1: Kelelahan Fisik dan Pergolakan Emosi Keluarga sebagai Dampak Merawat. Kelelahan fisik yang dialami keluarga berupa keletihan berdampak pada munculnya keluhan pusing, tekanan darah menurun, lemas, demam, dan berat badan menurun. Selain itu, pergolakan emosi tergambar dari keberagaman emosi keluarga saat merawat pasien pascapasung meliputi rasa marah, bosan, jengkel, dan malu.

Kelelahan fisik yang dialami keluarga dan emosi yang dirasakan keluarga merupakan dampak negatif yang dialami keluarga karena merawat anggota keluarganya yang sakit atau lebih dikenal dengan beban keluarga. Hal ini didukung oleh penelitian yang dilakukan oleh Grad dan Sainsbury (1966 dalam Rafiyah \& Sutharangsee, 2011) yang menyatakan beban adalah dampak negatif yang dirasakan keluarga karena merawat anggota keluarganya yang sedang sakit. Chadda, Singh, dan Ganguly (2007) menjelaskan bahwa caregiver atau keluarga yang bertanggung jawab merawat anggota keluarganya yang mengalami schizophrenia dan bipolar disorder akan mengalami beban hidup karena tanggungjawab yang kompleks dari caregiver pada pembiayaan, perawatan kesehatan pasien dan kebebasan serta aktivitas caregiver itu sendiri. Awad dan Voruganti (2008) menjelaskan bahwa beban dalam merawat merupakan dampak dan konsekuensi yang diterima oleh caregiver yang meliputi aspek emosional, aspek fisik, psikologi dan dampak ekonomi. Hoenig dan Hamilton (1966 dalam Rafiyah dan Sutharangsee, 2011) dan Montgomery, Gonyea, dan Hooyman (1985) mendefinisikan beban dalam kategori obyektif dan subyektif dimana beban obyektif merupakan kejadian atau aktivitas yang berhubungan dengan pengalaman negatif caregiver, sedangkan beban subyektif adalah perasaan yang dialami caregiver selama merawat. Hasil penelitian kelelahan fisik keluarga yang diikuti dengan keluhan pusing, lemas, tekanan darah menurun, dan badan kurus merupakan dampak atau beban objektif, sedangkan pergolakan emosi merupakan dampak atau beban subjektif caregiver.

Pergolakan emosi yang ditemukan pada penelitian ini adalah rasa marah, jengkel, bosan, dan malu.
Hal ini sejalan dengan hasil penelitian yang dilakukan oleh Hou, et al., (2008) yang menyatakan bahwa caregiver yang merawat pasien schizophrenia di Taiwan mengalami ansietas, rasa malu dan berdosa serta terganggu selama merawat pasien.

Peneliti juga menemukan emosi berbeda yang dirasakan oleh satu orang partisipan dan bertolak belakang dengan emosi yang dirasakan sebagian besar partisipan. Emosi berbeda itu adalah keluarga tidak merasakan marah dan tidak malu terhadap pasien pascapasung, melainkan merasa kasihan terhadap pasien. Kondisi ini terjadi karena keluarga dalam hal ini ibu kandung pasien sangat menyayangi pasien dan mempunyai koping diri yang sangat baik. Di samping itu, caregiver dalam hal ini ibu kandung pasien hanya memiliki tanggung jawab merawat pasien karena anakanak yang lain sudah mempunyai keluarga sendiri.

Tema 2: Kesulitan Keluarga dalam Manajemen Beban. Tema kedua hasil penelitian ini menggambarkan adanya kesulitan keluarga dalam mengatur beban selama merawat. Kesulitan keluarga dalam manajemen beban ini terlihat dari keterbatasan keluarga dalam merawat serta risiko pada pasien bila tidak ada yang mengawasi mereka. Keterbatasan keluarga dalam merawat dialami keluarga karena keluarga merasa sibuk, tidak ada anggota keluarga lain yang membantu merawat pasien serta keluarga tidak dapat bekerja apabila terus mengawasi pasien. Kesulitan keluarga juga berisiko terjadinya pelecehan seksual (dihamili) atau pasien hilang bila tidak ada yang mengawasi.

Munculnya kesulitan manajemen beban keluarga saat merawat dapat dilihat dari beberapa faktor yang memengaruhi beban. Rafiyah dan Sutharangsee (2011) menjelaskan adanya tiga faktor yang memengaruhi beban keluarga, yaitu faktor yang berasal dari keluarga atau caregiver sendiri, faktor dari pasien dan faktor lingkungan. Salah satu faktor dari keluarga yang mampu menjelaskan kesulitan manajemen beban adalah "Time Spent per Day" atau kebutuhan waktu perawatan pasien setiap harinya. Semakin tinggi atau banyaknya waktu untuk merawat pasien, semakin besar pula 
beban keluarga. Hasil penelitian ini juga didukung oleh Yi, Pin, dan Hsiu (2009 dalam Rafiyah dan Sutharangsee, 2011) yang menjelaskan adanya hubungan yang bermakna antara kebutuhan waktu perawatan pasien setiap harinya dengan beban keluarga. Li, Lambert, dan Lambert (2007) juga menjelaskan terdapat hubungan yang bermakna antara jumlah waktu yang diperlukan caregiver untuk merawat dengan beban obyektif caregiver.

Pasien pascapasung yang kembali ke rumah setelah perawatan di RSJ masih menunjukkan perilaku yang mengganggu lingkungan atau keluarga dan untuk memenuhi kebutuhan dasarnya masih banyak dibantu oleh keluarga. Hal ini didukung oleh penelitian Fujino dan Okamura (2009) yang menjelaskan bahwa ketidakmampuan pasien memenuhi kebutuhan dasarnya secara mandiri berpengaruh terhadap beban caregiver dimana caregiver mengalami keterbatasan waktu, tenaga dan perhatian. Penelitian lain dilakukan oleh Hou, et al., (2008) menjelaskan bahwa gejala klinis pasien yang mempengaruhi perilaku pasien mengakibatkan beban pada caregiver. Pasien pascapasung yang dirawat partisipan dalam penelitian ini menunjukkan gejala klinis yang hampir sama dengan pasien schizophrenia.

Hasil penelitian ini menjelaskan bahwa kesulitan keluarga dalam manajemen beban disebabkan oleh keterbatasan berupa tidak adanya anggota keluarga lain yang ikut membantu merawat. Partisipan dalam penelitian ini adalah satusatunya caregiver bagi pasien pascapasung. Penelitian yang dilakukan oleh Hou, et al., (2008) menjelaskan bahwa dalam merawat pasien schizophrenia dibutuhkan 2 atau 3 anggota keluarga lain yang membantu merawat selain caregiver itu sendiri. Hal inilah yang turut menjelaskan bahwa untuk merawat pasien dengan gangguan jiwa tidak cukup hanya seorang caregiver, namun juga anggota keluarga lain yang membantu tugas caregiver secara bergantian.

Tema 3: Perilaku Agresif Pasien sebagai Alasan Pemasungan Ulang. Hasil penelitian didapatkan bahwa pasien pascapasung setelah pulang dari perawatan di RSJ masih mengalami kekambuhan di rumah dengan menunjukkan bebe- rapa perilaku yang mengganggu lingkungan dan keluarga sendiri. Perilaku pasien yang mengganggu lingkungan antara lain berteriak-teriak, memukul, merusak, mengejar-ngejar, dan berhutang di warung sekitar rumah. Selain itu, perilaku pasien yang menggangu keluarga adalah mengamuk, merusak perabotan, dan bersikap kasar terhadap keluarga.

Perilaku pasien yang masih mengganggu keluarga dan lingkungan membuat keluarga memutuskan kembali untuk melakukan pembatasan gerak berupa pemasungan, antara lain diikat, dirantai, ditali, dikurung di dalam kamar, atau di rumah sendirian. Semua partisipan dalam penelitian ini menyatakan bahwa pemasungan ulang terjadi karena perilaku agresif dari pasien. Kondisi ini sejalan dengan hasil penelitian yang dilakukan oleh Puteh, Marthoenis, dan Minas (2011) tentang karakteristik pasien pasung di Aceh yang menjelaskan bahwa alasan terbanyak dilakukannya pemasungan adalah perilaku agresif dari pasien di samping alasan keamanan dan alasan khusus lainnya. Stewart, Bowers, Simpson, Ryan, dan Tziggili (2009) juga menyatakan bahwa terjadinya restraint atau pengekangan fisik lebih banyak disebabkan karena perilaku agresif atau perilaku yang membahayakan dibandingkan alasan manajemen di ruang perawatan. Namun, hasil yang berbeda didapatkan dari temuan Departemen Kesehatan (Depkes) (2005) yang menerangkan alasan terjadinya pemasungan di Indonesia disebabkan oleh kurangnya pemahaman keluarga akan kesehatan jiwa, rasa malu keluarga, beban penyakit yang tidak kunjung sembuh serta tidak adanya biaya pengobatan. Perbedaan alasan pemasungan ini dapat terjadi mengingat alasan yang disampaikan oleh Depkes berkaitan dengan alasan pemasungan yang dilakukan keluarga pertama kalinya, sedangkan alasan perilaku agresif pasien yang menjadi hasil temuan penelitian ini merupakan alasan terjadinya pemasungan ulang oleh keluarga.

Tema 4: Bentuk Dukungan Internal dan Eksternal pada Keluarga dalam Merawat. Dukungan Internal adalah dukungan yang berasal dari dalam keluarga, sedangkan dukungan eksternal adalah dukungan yang berasal dari luar 
keluarga. Hasil penelitian diketahui bahwa keluarga yang merawat pasien pascapasung atau caregiver mendapatkan berbagai macam bentuk dukungan yang berasal dari internal atau keluarga besar pasien dan dukungan eksternal atau yang berasal dari luar keluarga. Bentuk dukungan internal keluarga besar yang dimaksud dalam penelitian ini adalah dengan membantu memenuhi kebutuhan dasar pasien, mengajak pasien berbicara, mencari pasien bila hilang atau keluyuran, ikut mendoakan, menjaga perasaan pasien, dan memberi bantuan beras atau uang kepada caregiver.

Bentuk dukungan eksternal yang ditemukan dalam penelitian ini adalah dukungan dana dan dukungan lingkungan. Dukungan dana yang dimaksud dalam penelitian ini adalah bantuan pemerintah berupa fasilitas pelayanan kesehatan gratis untuk kontrol ulang dan pengobatan lanjutan melalui puskesmas terdekat. Bentuk dukungan eksternal lain dalam merawat pasien pascapasung adalah dukungan dari lingkungan antara lain mengingatkan pasien untuk memakai baju apabila tidak memakai baju di luar rumah, menanyakan kondisi pasien, memberi saran untuk mencari alternatif pengobatan lainnya, dan kepedulian aparat desa turut mengusahakan bantuan dana dari desa meskipun sampai saat ini belum terwujud.

Dukungan internal maupun eksternal pada keluarga dalam merawat pasien pascapasung sejalan dengan teori Friedman (2010) yang menjelaskan bahwa dukungan sosial keluarga adalah sebuah proses yang terjadi sepanjang masa kehidupan dan dapat berasal dari internal seperti dukungan dari suami/istri atau saudara kandung dan dukungan eksternal seperti budaya, agama, sosial ekonomi dan lingkungan. Friedman (2010) juga menjelaskan bahwa dukungan keluarga terdiri dari dukungan emosional, penghargaan, materi serta informasi. Konsep tersebut menjelaskan bahwa dukungan materi diperoleh caregiver dari keluarga besar pasien berupa bantuan tenaga, uang dan beras, serta bantuan pemerintah berupa fasilitas pelayanan kesehatan gratis bagi pasien pascapasung sangat berarti bagi keluarga. Penelitian Lai dan Thomson (2011) juga menyatakan bahwa penentu kebijakan pemerintah berpotensi tinggi untuk memberikan dukungan keuangan pada keluarga. Akan tetapi, bentuk dukungan emosional juga diperoleh caregiver dari keluarga besar maupun lingkungan sekitar. Bentuk dukungan informasi juga diperoleh keluarga pada saat memeriksakan pasien ke puskesmas.

\section{Tema 5: Peningkatan Pemahaman Spiritualitas sebagai Hikmah Merawat. Hasil penelitian ini} menjelaskan bahwa keluarga sebagai caregiver pasien pascapasung mendapatkan hikmah merawat dengan meningkatnya pemahaman spiritual keluarga. Peningkatan pemahaman spiritual tersebut terlihat dari penerimaan diri keluarga, kedekatan keluarga kepada Tuhan, serta hubungan keluarga dengan lingkungan. Partisipan menunjukkan penerimaan diri dengan menjadi lebih sabar, tidak mudah marah, dan mendapatkan banyak berkah. Kedekatan keluarga terhadap Tuhan ditunjukkan dengan menerima kehidupan yang dijalani sebagai takdir Tuhan, pasrah, dan menganggapnya sebagai cobaan atau ujian dari Tuhan.

Menjadi lebih sabar, tidak mudah marah, dan mendapatkan banyak berkah merupakan bentuk penerimaan diri keluarga terhadap kondisi kehidupan yang dijalani, yaitu merawat pasien pascapasung. Di sisi lain, dengan menganggap merawat pasien pascapasung merupakan takdir, cobaan dari Tuhan dan bersikap pasrah merupakan wujud kedekatan keluarga terhadap Ilahi. Keluarga mampu mencari arti kehidupan dengan merawat pasien pascapasung. Mauk dan Schmidt (2004 dalam Potter dan Perry, 2010) menjelaskan spiritualitas sebagai konsep komplek yang unik untuk setiap orang yang tergantung dari pengalaman hidup, kepercayaan, budaya dan ide-ide tentang kehidupan yang akan membuat seseorang dapat mencintai, memiliki kepercayaan dan harapan, mencari arti dalam hidup dan memelihara hubungan dengan orang lain. Pemahaman spiritual keluarga tidak hanya ditunjukkan dari sisi religi atau hubungan vertikal keluarga dengan Tuhan, tetapi juga ditunjukkan adanya hubungan horizontal antara keluarga dan lingkungannya melalui keikutsertaan keluarga dalam kegiatan di masyarakat. 
Kedekatan keluarga terhadap Tuhan menunjukkan peningkatan spiritual keluarga dari dimensi hubungan secara vertikal atau hubungan dengan Tuhan (transpersonal), sedangkan penerimaan diri keluarga merupakan bentuk keterhubungan keluarga dengan diri sendiri (intrapersonal), dan hubungan positif keluarga dengan lingkungan merupakan keterhubungan keluarga dengan lingkungan (interpersonal). Hal ini sejalan dengan konsep teori Miner dan Williams (2006 dalam Potter dan Perry, 2010) yang menjelaskan bahwa dimensi keterhubungan dalam spiritualitas terdiri dari keterhubungan dengan diri sendiri (intrapersonal), keterhubungan dengan orang lain (interpersonal) dan keterhubungan dengan Tuhan (transpersonal). Hasil penelitian yang sejalan dengan temuan penelitian ini adalah penelitian kualitatif tentang pengalaman keluarga merawat pasien halusinasi oleh Ngadiran, Hamid, dan Daulima (2010) yang menjelaskan bahwa keluarga pasien halusinasi mampu merawat dengan baik, tulus, ikhlas, menganggapnya sebagai cobaan dari Tuhan, pasrah menerimanya dan menjadi lebih sabar.

\section{Kesimpulan}

Keluarga atau caregiver pasien pascapasung mengalami kesulitan melakukan menajemen beban yang kemudian menimbulkan dampak berupa kelelahan fisik dan pergolakan emosi. Pasien pascapasung yang kembali dirawat oleh keluarga menunjukkan penurunan kondisi berupa munculnya perilaku agresif yang kemudian menjadi alasan dilakukannya pemasungan ulang oleh keluarga. Berbagai bentuk dukungan internal dan eksternal diperlukan keluarga dalam merawat pasien pascapasung. Selain itu, diketahui pula bahwa hikmah merawat bagi keluarga atau caregiver adalah peningkatan pemahaman spiritual. Saran penelitian adalah diadakannya pengembangan pelayanan keperawatan jiwa di masyarakat dan pemberian pendidikan kesehatan dengan cara penanganan pasien gangguan jiwa (DN, INR, MK).

\section{Referensi}

Awad, A.G., \& Voruganti, L.N. (2008). The burden of schizophrenia on caregivers. Pharmacoeconomics, 26 (2), 149-162.

Creswell, J.W. (2010). Research design: pendekatan kualitatif, kuantitatif dan mixed (Terj. Achmad Fawaid). Yogyakarta. Pustaka Pelajar.

Depkes RI. (2005). Masalah-masalah psikososial di Indonesia. Diperoleh dari http://www. depkes.go.id.

Dinas Kesehatan Bireuen. (2008). Laporan kesehatan tahun 2008. Tidak dipublikasikan. Nangro Aceh Darussalam: Dinas Kesehatan Kabupaten Bireuen.

Friedman, M.M. (2010). Keperawatan keluarga: Teori dan praktik (2rd Ed.). (Terjemahan). Jakarta. EGC.

Fujino, N., \& Okumura, H. (2009). Factors affecting the sense of burden felth by family members caring for patients with mental illness. Archieves of Psychiatric Nursing, 23, 128-137.

Hanzawa, S., Tanaka, G., Inadomi, H., Urata, M., \& Ohta, Y. (2008). Burden and coping strategies in mother of patients with schizophrenia in Japan. Psychiatric and Clinical Neurosciences, 62, 256-263.

Hou, S.Y., Ke, C.L., Su, Y.C., Lung, F.W., \& Huang, C.J. (2008). Exploring the burden of the primary family caregivers of schizophrenia patients in Taiwan. Psychiatry Clinical Neurosciences, 62, 508-514.

Jankovic, J., Yeeles, K., Katsakou, C., Amos, T., Morriss, R., Rose, D., Nichol, P., McCabe, R., \& Priebe, S. (2011). Family caregivers' experiences of involuntary psychiatric hospital admissions of their relatives- a qualitative study. PLoS One 6 (10), e25425. doi: 10.1371/journal.pone.0025425.

Li, J., Lambert, C.E., \& Lambert, V.A (2007). Predictors of family caregiver's burden 
and quality of life when providing care for a family member with schizophrenia in the people's republic of China. Nursing and Health Sciences, 9 (3), 192-198. doi: 10.1111/j.1442-2018.2007.00327.x

Lai, C., \& Thomson, D. (2011). The impact of perceived adequacy of social support on caregiving burden of family caregivers. Families in Society: The Journal of Contemporary Social Services, 92 (1), 99106. doi: http://dx.doi.org/10.1606/10443894.4063

Maramis, W.F. (2006). Catatan ilmu kedokteran jiwa. Surabaya: Airlangga.

Montgomery, R.J.V., Gonyea, J.G., \& Hooyman, N.R. (1985). Caregiving and the experience of subjective and objective burden. Family Relation, 34, 19-26. doi: 10.2307/583753

Ngadiran, A., Hamid, A.Y.S., \& Daulima, N.H.C. (2010). Studi fenomenologi pengalaman keluarga tentang beban dan sumber dukungan keluarga dalam merawat anggota keluarga dengan halusinasi di wilayah Cimahi dan Bandung (Tesis, tidak dipublikasikan). Fakultas Ilmu Keperawatan Universitas Indonesia, Jakarta.

Nevi. (2012). Jawa Tengah bebas pasung tahun 2012. December 20, 2012. Diperoleh dari http://www.dinkesjatengprov.go.id/.../jaten g_bebas_odm.
Potter, P.A., \& Perry, A.G. (2010). Fundamental of nursing (7th Ed.). (Adrina Ferderika \& Marina Albar, Penerjemah). Singapore: Elsevier.

Puteh, I., Marthoenis, M., \& Minas, H. (2011). Aceh free pasung: Releasing the mentally ill from psysical restrain. International Journal of Mental Health Systems, 5 (10), 1-5. doi: 10.1186/1752-4458-5-10.

Rafiyah, I., \& Sutharangsee, W. (2011). Review: Burden on family caregivers caring for patients with schizophrenia and its related factor. Nurse Media Journal of Nursing, 1 (1), 29-41.

Royal Collage of Nursing. (2008). Let's talk about restraint. Diperoleh dari https://www2.rcn. org.uk/_data/assets/pdf_file/0007/157723 /003208.pdf.

Stewart, D., Bowers, L., Simpson, A., Ryan, C., \& Tziggili, M. (2009). Manual restrain of adult psychiatric inpatients. $J$ Psychiatr Ment Health Nurs, 16 (8), 749-757. doi: 10.1111/j.1365-2850.2009.01475.x.

Yusuf, A.J., \& Nuhu, F.T. (2011). Factors associated with emotional distress among caregivers of patients with schizophrenia in Katsina Nigeria. Soc psychiat epidemiol, 46, 11-16. doi: 10.1007/s00127-009-0166-6. 